\title{
Microfinance Model- A Dynamic Drive Towards the Women Empowerment
}

\author{
Ruchi Patel \\ Centre for Studies in Economics and Planning, \\ Central University of Gujarat, Gandhinagar, India
}

Doi: 10.19044/esj.2017.c1p23 URL:http://dx.doi.org/10.19044/esj.2017.c1p23

\begin{abstract}
This study is based on the microfinance model which works for poverty reduction and financial inclusion mechanism for development of social systems and livelihood development in developing countries. Women are a powerful force that can be empowered to the benefit of their families, society and nation to which they belong. But in the rural and tribal area of Indian patriotic society, women face discrimination in their family with social, economic and political life. This study has examined the impact of microfinance on women empowerment in the context of various model and initiatives taken by programmes and schemes of government and nongovernment organisations. The methodology of the present study relies on case study method of women Self-Help Group (SHG). Secondary data has been collected from the annual and other reports of different departments and ministries, journals, books, research papers. This study suggest that microfinance played a very important to created financial resources for poor women but it requires investment in capacity building over a period of time, it will help to build the social capital and helps to bring economic prosperity.
\end{abstract}

Keywords: Empowerment, Microfinance, Self Help Group, Gujarat

\section{Introduction}

Mohammad Yunus, a Bangladeshi banker and economist who was awarded Nobel Peace Prize for founding Grameen Bank ${ }^{1}$ and pioneering the concept of microfinance. Microfinance is one of the most important economic tools to make a remarkable change in the social and economic life of the poor people especially in the developing countries. It was designed to engage people in economic activities that could help them to meet their basic needs. NABARD (2000) defines microfinance as "the provision of thrift, credit and other financial services and products of very small amounts to the poor in 
rural, semi-urban or urban areas enabling them to raise their income levels and improve living standards".

The successful model of Grameen Bank from Bangladesh draws the attention of people from all over the world. These approaches have emerged in India in the 1980s through the Self Help Groups (SHGs) model. The Self Help Groups (SHGs) emerged as an integral part of the Indian financial system after 1996. They are small, informal and homogenous groups of not more than 20 members. Each SHG is an association of people from same socio-economic class who come together for a large benefit. The people in SHGs come together for solving their common problems through mutual help. Villages face problems of poverty, illiteracy, and lack of awareness about health issues. These problems are mainly due to lack of resources. It is very difficult to deal with them individually, and hence group efforts are necessary to solve them. In the last couple of years, Governments and NGOs (Non-Government Organisations) have made a tremendous effort through microfinance to encourage women entrepreneurship. Self Help Groups make the way for microfinance by providing credit to the poorest sections of the society. NABARD and RBI (Reserve Bank of India) have been the backbone in promoting and linking SHGs to different national banks.

Women all over the world are discriminated even though their contribution is no less than men are. Amartya Kumar Sen in 1990 has coined the term 'missing women' and said that there were 100 million missing women. UNFTA in 2012 has made a survey and found that number of missing women was even higher at 117 million. Sen argued that the basic reason for the missing women is the discriminatory treatment rooted in the cultural preference for boys. In fact, both males and females should be equipped with equal opportunities to enhance their capabilities so that they get the freedom to choose their means of development and improve their lives. It has been noticed that in almost all societies, women not only have less power than men do, but they also get lesser wages and have less control over the resources. The contribution of women in the economy is equally valuable but their work is invisible. The reason for low 'visibility' of women is the effect of difference in the working pattern of both men and women where women have less access to resources and thus lower payments. For example when young girls and boys reach their juvenile age, girls are expected to spend more time doing household chores and learning kitchen work while boys spend more time in farming or doing odd jobs to earn wages. When they reach their adulthood, girls are more over pressured than boys because they take care of household activities and they go to work to help their mothers. In reality, they spend more hours in work but get lesser outcome in financial terms.

Women also suffer from different types of deprivation in social and economic spheres of life, including poor education and income, less control 
over their own income, less participation in decision-making, less access to production resources and reduced employment opportunities than men. According to the Gender Statistics Database (World Bank) 2016, gender inequality is a core development objective, a smart development policy and sound business practice. Gender equality can boost productivity, enhance prospects for next generation, build resilience and make institutions more representative and effective. It is true that women have less access to financial services and they remain in more disadvantaged position than men. We aim for inclusive economic growth, poverty eradication and sustainable development but to achieve all these, gender equality is must.

\section{Women Empowerment}

Empowering women in the process of development has been one of the main concerns of almost all development strategies and programs. Development agencies are now more concerned to raise the women's empowerment level, which will make them capable to challenge their dependency in the family and society (Selvaraj and Kannusamy 2007). Pandit Jawaharlal Nehru has rightly said, "When a woman moves forward the family moves and the nation moves". Mohammed Yunus has rightly said, "When men get a chance, they start dreaming about themselves; when a woman gets a chance, they dream about home and their children and they also dream about what they can contribute to the community". Even though lesser in numbers the contribution of women for economic growth, cannot be ignored.

Third World Feminists and Women's organizations presented the idea of 'Empowerment' for the first time in 1970s. The focus of this concept was to give an outline and provide support to the struggle for social justice and equality for women through transformation of social and political structures, and economic arrangements at national as well as international levels. This definition of empowerment strengthens the transformative approach. The concept of empowerment has received a great deal of attention during the past 20 years, due to its strong influence on organizational effectiveness and innovation (Spreitzer, 1995). Both government organizations and NGOs have been trying to adapt this management concept to achieve their goals and improve their operation in today's volatile environment. Empowerment is a concept shared by many disciplines and areas: Economics and Studies of Social movements, Community development, Psychology and Educational Organisations. The definition of empowerment relates more directly to power, as "A multidimensional and interlinked process of change in power relations".

- Power over, i.e. one person has power over other, which suggests an unequal relationship

- Power to, i.e. the ability to make decisions and find solutions 
- Power with, i.e. social or political power, exercised by people on a common ground

- Power within, i.e. self-awareness and esteem which enables people to influence their own lives

These power relations operate in different spheres of life (e.g. economic, social, and political) and at different levels (e.g. individual, household, community, market, institutional (Mayoux, 2000).The World Bank made an in-depth study on empowerment (Alsop, Bertelsen and Holland, 2006). Two main components; agency and opportunity structure were highlighted. Agency is the ability of individuals to make deliberate choices for themselves, whereas opportunity structure determines the degree to which participants can transform their agency choices into action. Within this framework, economic, social, political, and psychological resources are indicators of agency. The set of institutional policies, which govern choices available to people, and how individuals make choices is called opportunity structure. Opportunity structure influences the amount of power an individual has got over the agency. According to this framework, both agency and opportunity structures determine an individual's degree of empowerment. In addition to this, the analytic framework consists of three domains (the state, the market, and the society) and three levels (macro, intermediate, and local) that represent various geographical, economic, and socio-political contexts.

\section{Women: Better Clients of Microfinance}

In India, poverty and women are two sides of same coin. There is no doubt that women are poorest amongst the poor and they are bound to be vulnerable. Now the only way out is to make a strong platform for the growth of women, which empowers them to make their own choices and thereby contribute for the economic growth as well as development. It is true that many microfinance institutions prefer women members, as they believe that they are trustworthy, better at work and more reliable borrowers, which helps in contributing to their own financial condition (Swain \& Wallentin, 2007).

\section{- Women and Poverty}

Women are among the world's poorest people. The Human Development Report, 1995, reported that 70 percent of the 1.3 billion people, living on less than $\$ 1$ per day are women. Women have a higher unemployment rate and lesser access to financial services than men do in almost every country of the world. Microfinance institutions can significantly reduce women's vulnerability by providing access to finances for incomegenerating activities. 


\section{- Women and Inequality}

UNDP, UNIFEM, and the World Bank, all indicate that gender inequalities in developing societies inhibit economic growth and development. Gender equality implies a society in which women and men enjoy the same opportunities, outcomes, rights and obligations in all spheres of life. Equality between men and women exists when both are able to share equally in the distribution of power and influence; have equal opportunities for financial independence through work or through setting up businesses; enjoy equal access to education and the opportunity to develop personal ambitions. (Cheston \& Kuhn, 2002).

\section{- Women and Household}

When women are empowered, the whole family gets the benefits. These benefits often have ripple effects on future generations. Women are also more likely to invest additional earnings in the health and nutritional status of the household and in children's schooling. This means that the giving benefit to women have a greater positive impact on child and household poverty reduction, measured in terms of nutrition, consumption and well-being. Assisting women therefore generates a multiplier effect that enlarges the impact of the institutions' activities.

\section{- Women and Work}

Women work plays an important role in development goals such as poverty reduction, human development and economic growth. It also transforms the lives of women by addressing gender inequalities at various levels. Women Participation in formal economic activities or work reflects the productive capacity of women, control over their own incomes and improves decision-making power. The ability to work outside and to engage in activities other than household can lead to significant strength, status and transformation of gender relations and challenge the traditional approach of social and economic relation.

\section{Studies on Micro Finance and Women Empowerment}

Hossain (1988) has examined Grameen bank participant members and non-participants also. He discovered that average household income was 43 percent higher than target non-participants in villages. Other than this the Grameen members were also found to be of younger age and better educated than non-participants. Grameen members spent 8 per cent more per capita on food and Grameen loans generated self-employment activities.

According to the Hashemi (1996) women's access to credit has an impact on their lives. Their results imply that women's access to credit contributes significantly to the magnitude of the economic contributions 
reported by women, to the likelihood of an increase in asset holding of their own, an increase in their exercise of purchasing power, and in their political and legal awareness and also uses composite empowerment index. He found that access to credit was also associated with higher levels of mobility, political participation and involvement in 'major decision-making' for particular credit organization

Mayoux (1997) states that a small increase in income of the women also leads to a decrease in male's contribution in income to certain types of household expenditure whereas, others believe that investing in women's capabilities empowers them to make choices which is not only a valuable goal in itself but it also contributes to greater economic growth and development.

Traceyet.al. (2006) has studied the economic empowerment of women from rural areas in India self-help through participation. These women were given training in stitching, embroidery, patch work, through Seva Mandir NGO in Udaipur. Women had to devote more time to the center as a result they had less time for household duties. Stress and pressure of work were the challenges they had to face. Positive result is that there was increase in their economic strength. This gave them great psychological relief.

Ashraf et.al (2008) has remarked that committed producer creates positive impact on decision making power and savings habit. She can take decision about withdrawing money or to roll-over balances. Commitment funds are to be used for certain purposes. Savings makes a woman powerful. Self-control on account has positive effect on female decision making power. Marketing also plays important and vital role. Bank staff members can encourage one to set saving goal and can persuade them for saving.

Microfinance programs have an important role to play to reduce poverty and empower poor women. It has been found that micro-finance services have positive impact on reducing poverty, improving standard of living and empowering poor women at international (Hashemi et al.1996; Yunus\& Jolis,1998;Banu et al., 2001; Hoque, 2008; Swain \&Wallentin, 2011) and national level (Singh, 2001; Todd, 2001; Borbora and Mahanta, 2008; Noreen, 2011; Sarumathil and Mohan 2012). On the other side, some research studies have shown negative impacts. Loans from the microfinance programs are mainly used for non-income generating activities such as consumption and other emergency needs. Some studies have also found that there is no significant impact of the program on generating income, reducing poverty and women empowerment. (Amin 1993; White, 1995; Coleman, 1999; Narayanan, 2003; Sarangi, 2007; Aslanbeigui et al. 2010). Analyzing these types of microfinancial services issue is significant for researchers and academicians. So this Paper main objective is to will examine impact of Microfinance on women empowerment. 


\section{Methodology}

Research method is a logical and systematic plan prepared for directing a research study. The method used in this study is the evaluation and the descriptive survey method. The study is based on primary data as well as secondary data and information. The descriptive method is suitable because the research work involved data collection from rural community members of microfinance institutions (MFIs) with a view to determine whether or not microfinance contribute to poverty reduction by increasing their income and welfare. The qualitative and quantitative information on SHG members and their households was obtained only through interviews. Multistage random sampling has been use for the data collection. For these study, From the Gujarat State Dahod District SHG has been selected because According to census 2011 in Gujarat state Dahod has second highest population of Scheduled tribes. The selection of SHG base on one criteria they should taken loan at least once from financial institutions. From each SHG 3 respondents selected randomly. In total, 180 members of SHGs were selected for the study. For the data analysis Average and percentage analysis was carried out to draw meaningful interpretation of the results. One simple case study also shows the impact of this programme.

\section{Socio Economic Profile of SHG Members}

Majority of the women respondents in SHG belong to the middle age group. In the study area of Dahod (tribal district). Women between the ages of 26-35 years are actively participating in SHG. Out of total 51.1 percent women belong to this age group. 31.1 percent of women belongs to $36-45$ age. In younger age group means less than or equal to 25 women are participation are only 6.7 percent. The more than 46 age women are also members of SHG, and constitute only 11.1 percent in Dahod. According to the field survey 35 percent respondent are illiterate and 20 percent of the women can sign in Dahod district. Out of the total literate women 16.1 percent women have received primary education, 21.1 percent women have received secondary education and 6.1 percent have received higher secondary education. Only 0.6 percent women are graduate. Not a single woman is a post graduate. Any other course include diploma, ITI and others has only 1.1 percent. In Dahod major two type sub caste in tribes. The Patelia is known to be a much higher Tribe/Sub-caste than compared to Bhil. And hence there is huge discrimination and difference between both the Tribes/Sub-castes. They don't even allow cross marriages to take place within one another. Table clearly shows that 77.8 percent of respondents belongs to schedule tribes in Dahod district where as 17.2 percent respondents belongs to the other back ward caste. Only 5 percent respondents belongs to schedule caste. No single respondent from the general caste. All women are from Hindu religion. Out of total 92.2 percent of beneficiaries are 
married, unmarried women constitute 3.9 , and 2.8 percent widow respondents in the SHG. $99(70.9 \%)$ respondents were from nuclear families and 81 respondents $(29.1 \%)$ had live in joint families. Dahod is tribal area so 78.3 percent of the respondent have land, only 18.9 percent respondent live in pakka house (concrete house). 68.9 percent of the respondents got loan up to Rs.10000 and 31.1 percent of respondents got Rs. 10001- 20000.

\section{Impact of Microfinance on women Empowerment}

\section{Changes in Monthly Income of SHGs Women}

The shows the monthly income of SHG's women who are 180 in number. Before joining the SHG 2.2 percent women were unemployed whereas after joining the SHG their number has gone down to 0.6 percent. The variation in unemployment rate is 1.6 percent. Those who are doing handicraft, agriculture and allied activity and casual labor some of them earned up to Rs.1000 only but after joining it there has been significant change in the employment level. After joining the SHGs their percentage has gone down from 72.2 percent to 40 percent. Which is praise worthy because after joining the SHG there has been a sharp rise in the level of income? That means a variation of 32.2 percent. In contrast the income group of Rs. 1001-2000 where earlier there were 23.3 percent respondents, now there are 47.2 percent. We can see income group of Rs. 2001-3000 total number of women increase from 2.2 percent to 7.2 percent. Before joining SHG no single women was earn more than Rs. 3000 but after joining SHG 9 women earn more than Rs. 3000. After getting a loan 70 percent members use it for productive activities such as purchase of stitching machines, raw material for the handicraft, buying a seeds and equipment for increased the agricultural production and cattle. Thus, we can conclude that there has been progressive economic empowerment in Dahod area due to joining of the SHGs.

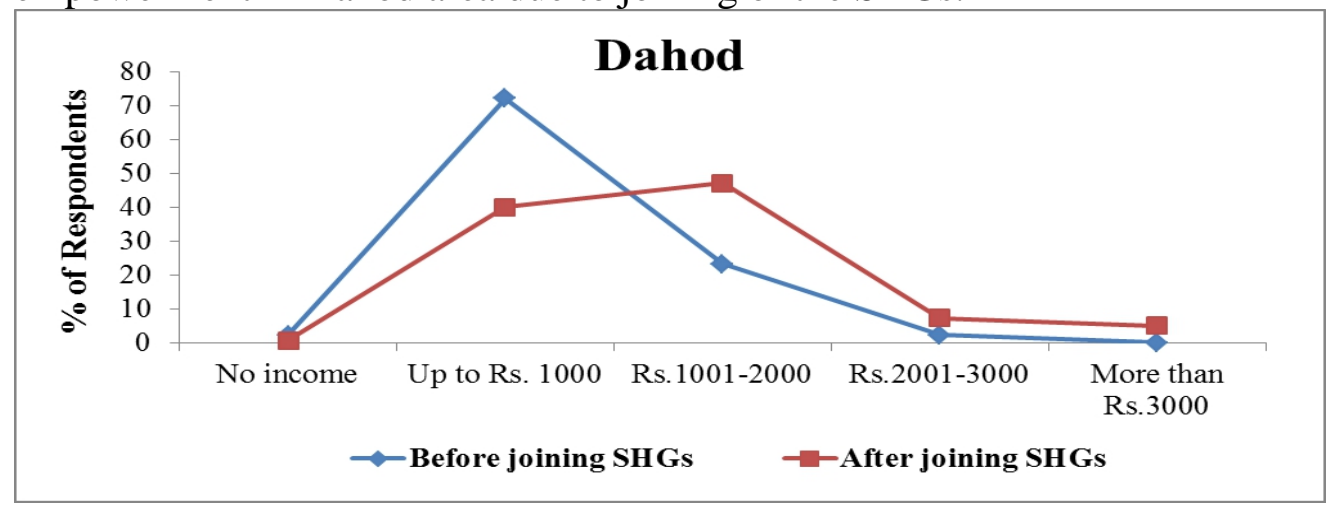

\section{Saving}

Savings gives confidence in life, which increases the efficiency towards work. The amount of personal saving helps them to recycle the 
amount and offer it as security to avail loan from the banks to which they are linked. Women always think about the future of the family and their children. The changes in the saving pattern are noticed due to change in the income of women. Income is divided into two parts; expenditure and savings. Income affects in both the parts and it is interrelated. Savings and micro-credit are the two important pillars. They cannot opt for one without the other. The basic aim of SHG is to develop thrift among the marginalized sections of the society. Saving, particularly among rural women, reduces dependency on noninstitutional sources and helps develop self-reliance. Contribution of a fixed sum on monthly basis as saving assumes greater importance as it directly influences the growth of common fund of the group. The accumulated savings which is the prime source of SHG fund is lent to the group. The greater the amount of savings the greater will be the ability of the group to meet the requirements of its members, as well as, higher will be its ability to demand additional funds from the formal financial institution.

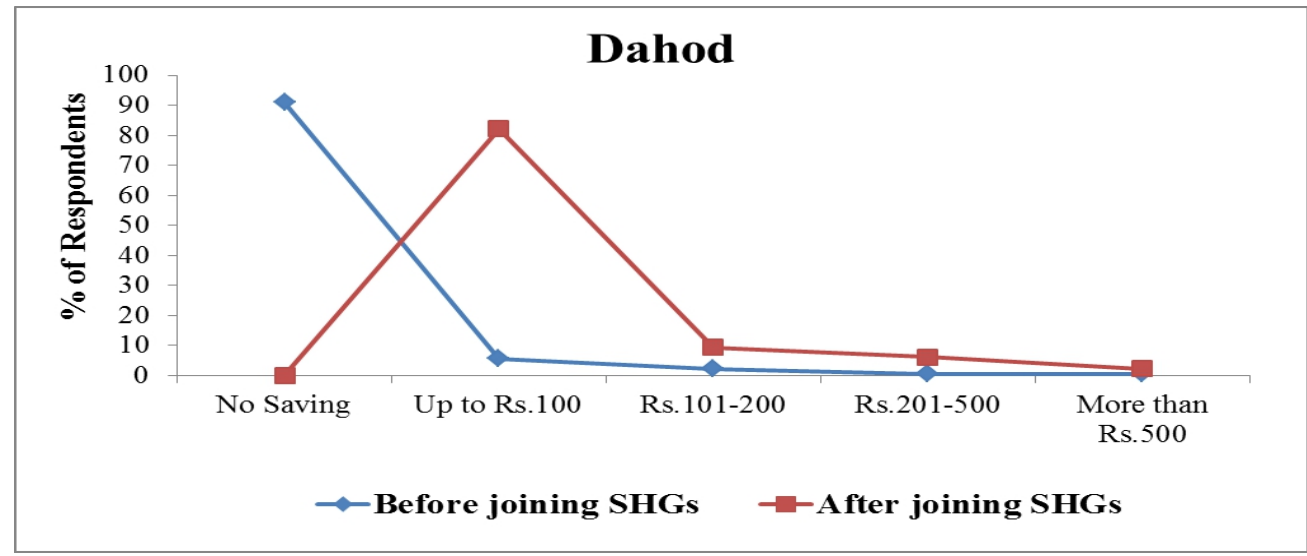

It shows the monthly individual savings of members of SHG. This table shows a drastic change in the saving pattern after joining the SHG. Women always think about the future of the family and their children. The data from the table clearly shows that 91.1 percent respondents did not have any savings before joining the SHG. It means all women in the SHG started saving after joining the SHG. Before joining SHG 5.6 percent respondents used to save money up to Rs. 100 in the bank or post office or Mandali, but now 82.2 percent respondents are saving because of SHGs. A drastic variation (76.6) in saving is noticed after joining SHGs. The women who save Rs.101200 and Rs. 201-500 have increased from 2.2 percent to 9.4 percent and 0.6 percent to 6.1 percent respectively. Only single woman saved more than Rs. 500 per month before joining the SHG. But after joining the SHG, four women have saved. This data itself shows that the after joining SHG economic empowerment of women has increased. The first aim of SHG to motivate the saving of women. It is fulfill at grass root level also. 
Changes in Participation of SHGs Women in Financial Decisions in Dahod

\begin{tabular}{|c|c|c|c|c|}
\hline \multirow[b]{3}{*}{$\begin{array}{ll}\text { Participation } & \text { in } \\
\text { Financial Decisions }\end{array}$} & \multicolumn{4}{|l|}{ Dahod } \\
\hline & \multicolumn{2}{|l|}{ Before joining SHGs } & \multicolumn{2}{|c|}{ After joining SHGs } \\
\hline & $\begin{array}{ll}\text { No. } & \text { of } \\
\text { Respondents } & \end{array}$ & $\%$ & $\begin{array}{l}\text { No. of } \\
\text { Respondents }\end{array}$ & $\%$ \\
\hline Nil & 37 & 20.6 & 21 & 11.7 \\
\hline Partial participation & 112 & 62.2 & 89 & 49.4 \\
\hline Full Participation & 31 & 17.2 & 70 & 38.9 \\
\hline Total & 180 & 100 & 180 & 100 \\
\hline
\end{tabular}

Source: Primary Survey 2014.

Table no. 6.15 shows the women participation in the household financial decision before and after joining SHGs in Dahod district. Positive changes of Women involved in the household financial decision-making are definitely considered as more empowered. They are able to participate in financial decision making like, expenditure, budget allocation, savings, buying and selling of household durables etc. Before joining SHGs 20.6 percent of women have not participated in financial decision but after joining SHGs 11.7 Percent have not participated in Dahod district. In the tribal area there is male domination in all aspect. It has been noticed that 62.2 percent of the women have partially participated in financial decision before joining SHGs. 49.4 percent of respondents partially participation of the financial decision. Only 17.2 percent of the women have fully participated before joining SHGs, but after joining SHGs 38.9 percent women respondents are fully participate in financial decision making. The level of financial participation has positive change before and after joining SHGs.

The microfinance program helps the economic status of women and they feel more empowered within their family. The more income a woman is able to generate the more she can lend a helping hand in the family which improves her respect and the family members treat her with dignity. The income earned by a women also enables her to take part in the financial decision making process of the family. When the woman has her own money in her hand then she has full right over it which also increases her financial literacy to use it in a productive manner. This also gives a good opportunity to come out of the age old male domination over monetary matters in our country.

\section{Case study of Mangalam Amul Parlour for Livelihood Promotion}

India contributes to $15 \%$ of the global milk production and stands as the largest producer of milk in the world with a production of 122 MMT in 2011. The size of Indian Dairy Industry is estimated at around USD 60 billion (INR 2,662 billion) with a good annual growth rate in terms of volume. The 
production \& demand for milk is expected to continue and rise due to various factors including population growth, rise in income \& changing life style.

Gujarat is one of the largest milk producing states in India with the contribution of $7.75 \%$ share in the total milk production of India. The state having 17 Cooperative dairy milk unions \& 25 private dairy plants has a milk collection of 3.45 billion litres with over 30 lakhs milk producers, affiliated to more than 15,000 Primary Milk Cooperative Societies. Milk contributes to 22 percent to the Agricultural GDP of Gujarat and is one of the biggest sectors for supporting livelihood in the state. As per state census data, out of about 102 lakhs total household of Gujarat, 42.6 lakhs households are engaged in Dairy and Animal Husbandry sectors as a primary or secondary source of their income. Though the dairy sector is active in most of the districts, some of the districts still need to be brought in the active dairy network. GLPC ("Mission Mangalam" Goverment Programme for SHG entrepreneurship development) is involved in promoting livelihood in the dairy sector by facilitating technical and financial assistance to the beneficiaries through various Central and State sponsored schemes.

Kiran ben is forty-one year old, working as a secretary of 'Yashoda Mata Mandal (Name of the SHG)'. She is very enthusiastic and a hard working woman. Before joining SHG she worked in the agriculture sector. She states that "Times were such that I was going through financial constraints as the income was uncertain in the agriculture sector and because of which it was not possible for me to take care of the upbringing of my children optimally". Coordinator of Mission Mangalam suggested and motivated women like her to create and join the SHG group. The cluster coordinator educated them that they will have to accumulate their savings till six months and after six months they will get the loan. She further adds that "Initially I joined for the purpose of saving which might have been useful for my children in future". In search of income and most significantly livelihood, under Mission Mangalam, an innovative initiative of the Government of Gujarat has been taken to empower rural women. Some women came together to form Sakhi Mandal (Self-help Group) and initiated the thought of savings. She says that "Facilitated by Mission Mangalam, I decided to start the Amul Mangalam Parlour with the intervention of Gujarat Milk Co-operative Federation (GMCF).

She quotes that "When I started, I had doubts on our own capabilities whether I would be really able to manage an income generating activity for my own self. My mind was filled with fear and uncertainty. I was totally confused. The coordinator of Mission Mangalam, helped me to imbibe selfbelief." She adds "We had no knowledge about the actual expenses of setting up and managing the Amul parlor. But that was the whole point, to come out of ignorance and grab this opportunity with both the hands". Showing the accounts register, Kiran said "I keep the accounts of the parlour on a daily 
basis in which I keep track of the stock that comes in and understand how much it is worth. Not a day has passed where I have not maintained systematic accounts of the things sold on a particular day. Now I have started keeping my household expenditure account. I have also started keeping my household expenses record which I was not keeping," she added. Asked about how you balance both household work and the job on other hand, she said she spends morning time for household work and in the afternoon she handles the parlor. The parlor was inaugurated in 2013 but with regular publicity in and around the village and amongst the school children, the sales has picked up by all means. Initially she was not able to earn that much of profit but now she earns good amount around Rs.8,000 to 10,000 per month. But during summer time she also earns more than Rs.10,000 per month. She also paid her loan amount which she had taken from bank. Because of the rise in her income now she can save more for her children's future and take care of them in much better manner and confidently participate in the financial decision making at her home. She feels that her self-confidence has increased more than what she had few years back. "Through whatever Iearn, I wish to educate our children and see them successful in life. I have not got that opportunity but I will not deprive my children of that opportunity for sure". Kiran smiles happily as she is feeding better food to her children and manages her family quite well. Mission Mangalam has given her a sustainable source of livelihood which has changed her life.

\section{- Problems of Non-cooperation among Members}

The GLPC works as a catalyst between banks and women entrepreneurs by giving financial assistance to start entrepreneurial activities under the Mission Mangalam Yojana. The Amul Mangalam Parlor concept is to generate income through group participation. But in the above case, Kiranben complains that although, the Mangalam parlor being a group activity earning project, she doesn't get any support from the other members in the group and the group has not initiated any joint management work till date. When other members were asked about this, they turned the tables by telling that Kiran ben is not ready to share the profits so she doesn't allow anyone to share work in the parlor. Thus such disputes are part of such big concepts like the Mission Mangalam Yojana, but with proper planning and leadership such good concepts can be profitable to many people at a time.

\section{Conclusion}

It has been found from the observation that microfinance has been successful in developing sustainable household livelihoods, and decreasing household vulnerability and community development up to a great extent. The microfinance has enabled women to make a greater contribution to household 
income through their own economic activities. This contribution is recognized and valued by other household members and lead not only to increase household well-being, but women's increased role in decision making and improved well-being for women themselves. This increased status in the household in itself in turn gives women the support they need to enable them together with the men to bring about wider changes in gender inequality in the community. The group activity has given them a chance to come out to the mainstream, to realize the potentialities within themselves. This has led to a chance in their outlook towards society. The status of being a woman is no more considered as curse. All these, in fact are looked upon as boon to bring them closer, to bind them closer and as a mean to lay the foundation of a new gender equality society.

The transformation of any society has to begin from women because women are the center of a family- the foundation stone on which the family is built. When a woman is changed, the family is changed, and change in the family brings change in society. The SHG approach is playing tremendous role as it is process oriented approach. Members of the group automatically become assertive after joining SHG. In the process, awareness is created on their rights and many other welfare aspects in the group.

\section{References}

1. Alsop, R., M. Bertelsen, and J. Holland. (2006). "Empowerment in Practice: From Analysis to Implementation", Poverty Reduction Group, World Bank, Washington, DC.

2. Amin, R., Becker, S., and Bayes, A. (1998). "NGO-Promoted Microcredit Programs and Women ees Empowerment in Rural Bangladesh: Quantitative and Qualitative Evidence", The Journal of Developing Areas, Vol. 32(2), pp. 21-36.

3. Ashraf, N., Karlan, D. and Wesley, Y. (2008). "Female Empowerment: Impact of a Commitment Savings Product in the Philippines", Yale University, Working Paper.

4. Aslanbeigui, N. Oakes, G. and Uddin, N. (2010). "Assessing Microcredit in Bangladesh: A Critique of Concept of the Empowerment", Review of Political Economy, Vol. 22, No. 2, 181-204.

5. Chenston, S. and Kuhn, L. (2002). "Empowering Women through Micro-finance", UNIFEM for Microcredit Summit 2002. Retrieved 28 February 2004 from http://www.microcreditsummit.org/papers/empowering_final.doc.

6. Hashemi, S. M. (1997). "Building a Capacity for Banking with the Poor: the Grameen Bank in Bangladesh", Edited by- HartmutSneider, Organization for Economic Co-operation and Development, France. 
7. Hashemi, S.M., Suler, R. S. and Riley, A. P. (1996). "Rural Credit Programs and Women"s Empowerment in Bangladesh", World Development, Vol. 24(4), pp. 635-653.

8. Hossain, M. (1988). "Credit for the Alleviation of Rural Poverty: The Grameen Bank in Bangladesh", IFPRI, Research Report No. 65, Washington D.C.

9. Mayoux, L. (1997). "The Magic Ingredient? Microfinance and Women "s Empowerment", A Briefing Paper prepared for the Micro Credit Summit, Washington.

10. Mayoux, L. (2000). "Microfinance and the Empowerment of Women: A Review of the Key Issues", Social Finance Unit Working Paper 23, ILO, Geneva.

11. Mayoux, L. (2000). "Microfinance and the Empowerment of Women: A Review of the Key Issues", Social Finance Unit Working Paper 23, ILO, Geneva.

12. Mayoux, L. (2005). "Women"s Empowerment through Sustainable Micro-Finance: Rethinking „Best Practice”, A Discussion Draft, and The University of British Columbia.

13. Narayan, D. (2002). "Empowerment and Poverty Reduction: A Sourcebook", Washington, World Bank.

14. Noreen, S. (2011). "Role of Microfinance in Empowerment of Female Population of Bahawalpur District", International Conference on Economics and Finance Research, IPEDR, Vol.4, IACSIT Press, Singapore.

15. Parwez, S., Patel, R. \& Shekar, K.C. (2017). "A Review of Microfinance-Led Development: Evidence from Gujarat". pp 1-12 Global Social Welfare. https://doi.org/10.1007/s40609-017-0095-3

16. Saraswathy, Anna, K.P .and Panicker, K.S.M. (2008). "Microcredit and Women Empowerment: A study in India", International Journal of global Business, Vol.1 (1), pp. 184-213.

17. Sarumathi, S. and Mohan, K. (2011). "Role of Micro Finance in Women "s Empowerment",Journal of Management and Science, Vol. 1, No.1, pp. 1-10.

18. Selvaraj, A. and Kannusamy, K. (2007), "Empowerment of Women in the Present Scenario: Issues and challenges", New Century Publications, New Delhi.

19. Singh, K. (2010). "Microfinance: Profiting from poor", Economic and Political Weekly, Vol. 45(18), pp. 4-5.

20. Spreitzer, G. (1995). "Psychological Empowerment in the Workplace: Dimensions, Measurement and Validation," Academy of Management Journal, Vol. 21(46) pp.1442-1465. 
21. Swain, R \&Wallentin. (2007). "Does Microfinance Empower Women Evidence from Self Help Groups in India”,Working Paper 2007:24, Uppsala University. http://www.nek.uu.se.

22. Yunus, M. (2002). "Grameen Bank II: Designed to Open New Possibilities", Accessed to - http.//www.grameen info.org/bank/bank2.html 